\title{
Development of Remote Laboratory for Distance Learning Practicum Online And Real-Time Digital Electronics Subjects
}

\author{
Hendra Jaya $^{1}$, Lumu ${ }^{2}$, Sapto Haryoko ${ }^{3}$, Sutarsi Suhaeb ${ }^{4}$ \\ ${ }^{1}$ Electronics Engineering Education, Universitas Negeri Makassar \\ Email: hendra070982@gmail.com \\ ${ }^{2}$ Electronics Engineering Education, Universitas Negeri Makassar \\ Email: lumu@yahoo.com \\ ${ }^{3}$ Electronics Engineering Education, Universitas Negeri Makassar \\ Email: haryoko@yahoo.com \\ ${ }^{2}$ Electronics Engineering Education, Universitas Negeri Makassar \\ Email: sutarsi.suhaeb@unm.ac.id
}

(Received: January-2020; Reviewed: January-2020; Accepted: March-2020;

Available online: March 2020; Published: April-2020)

\begin{abstract}
This study aims to find out: 1) how to Develop Remote Laboratory as a new tool for online and realtime practicum learning in digital electronics; 2) how to use Remote Lab that meets the valid, practical and effective criteria. This research is a type of research and development $(R \& D)$ where the product can work effectively and be ready to use. The development of hardware and software in the form of Remote Lab media is carried out with an engineering approach. The use of Remote Lab can be applied at the Vocational School by looking at the results of the development based on the validation of the material experts (Content Aspect with very good category, and the Design Practicum aspect with a very good category), validation of media experts (Aspect of Visual Display in the excellent category, real-time aspects in the excellent category, programming aspects in the excellent category), Analysis of the Effectiveness and Practicality of Using Remote Labs with the category very effective, then Practical Assessment of Remote Lab products with a very practical category. The creation of online and realtime distance learning practicum systems that can facilitate students who are constrained by distance and inadequate school facilities.
\end{abstract}

Keywords: Remote-lab, online, realtime, distance learning, practicum

\section{INTRODUCTION}

The use of hands-on laboratories can cause students to experience psychological barriers in carrying out practical work. In addition to being expensive in procuring materials and operating costs and less flexible, hands-on laboratories also make students less comfortable at work, such as the emergence of fear of damage to the equipment to be used (J. Ma \& J. V. Nickerson, 2006). Such conditions can cause a decrease in student motivation in participating in practical activities. At present a variety of computer applications have been developed to support the implementation of V-Labs which are believed by education experts to increase flexibility in terms of time allocation and place for practicing. Practicum activities with V-Lab can provide an efficient level of financing because it is based on simulators created using computer programs.

Another demand of a practicum activity is the existence of collaborative work among students. Collaborative work in practical activities is very important because it is able to motivate individuals in group work, and is able as a means for mutual learning between individuals 
(Kask, 2009). V-Lab can be implemented easily and at low cost. The use of V-Lab also provides a positive perception of the aspects of product appearance and ease of operation and can increase student motivation in carrying out practicum (Muchlas, 2014).

Virtual Laboratory is a computer software that has the ability to do mathematical modeling of computer equipment that is presented through a simulation. Virtual laboratories are needed to strengthen understanding of concepts in the learning process. The Virtual Laboratory is not a substitute but a part of the real Laboratory that is used to complement and correct existing weaknesses (Purwanti Widhy, 2012). The weakness of VLAB is that the Virtual Laboratory does not provide real field experience (Hendra, 2013).

The Remote Lab (RL) concept is a relatively new concept built but the number is exponentially increasing due to the latest technological advancements and the availability of tools to design it. Remote labs are the best alternative for working in a real laboratory because if well designed they can offer students: 1) tele-presence in the laboratory (tele-presence); 2) Can experiment on real equipment; 3) can collaborate; 4) Learning by trial and error; 5) can conduct analysis on real experimental data; and 6) Flexibility in choosing the time and place to conduct experiments. The main advantages and disadvantages of each type of laboratory are summarized in Table 1.

From table 1 shows that the advantages of "remote lab" can cover the shortcomings that exist in real laboratories and virtual laboratories. Thus the shortcomings of the "remote lab" are only the presence in the laboratory and the initial competence possessed to operate the equipment must be relatively higher (having advanced electronic capabilities).

Table 1. Comparison of Advantages and Disadvantages of Real Labs, Virtual Labs, and Remote Labs (Zorica Nedic. 2003)

\begin{tabular}{lll}
\hline Laboratory Type & Advantages & Disadvantages \\
\hline Real & $\begin{array}{l}\text { realistic data } \\
\text { interaction with real equipment } \\
\text { collaborative work } \\
\text { interaction with supervisor }\end{array}$ & $\begin{array}{l}\text { time and place restrictions } \\
\text { requires scheduling } \\
\text { expensive } \\
\text { supervision required }\end{array}$ \\
\hline Virtual & $\begin{array}{l}\text { good for concept explanation } \\
\text { no time and place restrictions } \\
\text { interactive medium } \\
\text { low cost }\end{array}$ & $\begin{array}{l}\text { idealized data } \\
\text { lack of collaboration } \\
\text { no interaction with real equipment }\end{array}$ \\
\hline Remote & $\begin{array}{l}\text { interaction with real equipment } \\
\text { calibration } \\
\text { realistic data } \\
\text { no time and place restrictions } \\
\text { medium cost }\end{array}$ & only "virtual presence" in the lab \\
\hline
\end{tabular}

After observing the Department of Electronics Engineering FT UNM, it was found that the competency possessed by FT UNM Electronics students was still low. On the other hand student interest to enter the Laboratory for practical activities is also still low. Taking into account the various demands of the implementation of practicum in the electronics field, it is necessary to develop Remote Labs that can provide online and realtime collaborative work facilities with more attractive devices so that later they can facilitate students in the practicum process so that they will be motivated, thereby affecting their competence.

Practicum Learning. According Soemanto (2003: 113) practical activities are included in learning activities, so someone who carries out an activity, training, or practical activity usually wants to achieve certain goals in order to develop aspects or potentials that exist in him. Sege (2005: 21) states that practical activities are the implementation of work in accordance with the job sheet provided by the instructor on subjects taught to determine students' mastery of cognitive and psychomotor abilities. Jobsheet is carried out to create a media that can support students' independence in practicum activities and increase the effectiveness of learning (Rini Widyastuti, 2018).

The process of teaching and learning vocational practice, both laboratory and workshop practices are characteristic of the teaching and learning process in vocational schools, in addition to the theory learning 
process. These practical teaching and learning activities require abilities in the cognitive, psychomotor, and affective domains. Orlich et al (2007: 67-68) states, "the cognitive domain encompasses objectives that deal with recall recognition of knowledge and the development of intellectual abilities and skills". With the understanding that the cognitive domain includes goals / outcomes related to memory or the introduction of knowledge and the development of intellectual abilities and skills.

Larson's analysis in the fields of skills, technology and acupation explains that teachers must be able to manage the PBM stages in the field of practical studies. The teacher can assess students' skills, knowledge, and attitudes according to their learning goals. Good practice management learning is an ability that must be possessed by every vocational school teacher in skills, technology or occupation so that teaching objectives can be achieved optimally.

To get understanding, knowledge, and skills in a particular vocational field, a person must experience, do, and cultivate the field in other words, the teacher's ability in learning practice is determined by the teacher's ability to understand the material being taught. The success of vocational and technology teachers in practicum learning is determined by their industry experience because vocational education will prepare graduates to be ready to work in the world of work and industry.

There are several practical learning methods that can be used, among others, the demonstration method, experimentation, performance, programmed learning methods, and practicum methods. According to Yamin (2005: 69), the use of demonstration and experimental methods can be applied provided that the teacher has the expertise to demonstrate the use of tools or carry out certain activities such as actual activities.

The Remote Laboratory concept. Remote $\mathrm{Lab}$ is a tool or device designed to teach collaborative work skills, because it offers an interesting perspective for social and collaborative based learning. However, the remote lab separates users (praktikan) from real work tables and tools. Thus the teleoperating method of remote lab equipment requires an efficient level and interactivity and clarity to the user to give the impression of truly being in a laboratory.

Remote Lab can be a complementary resource for practical learning that is useful for laboratory activities on a "Hands-on", because it allows for monitoring or monitoring experiments that run remotely (online). Hands-on labs, where students operate real equipment or manipulate real objects when they are in direct contact with tools and objects in the same room will remain existential in technical education, because the experience of learning in real life situations is not only a major prerequisite for learn psychomotor skills, but are also relevant for understanding theoretical concepts (Dieter Müller, 2007).

Researchers (Ma \& Nickerson, 2006) emphasize the effectiveness of using remote labs in experiments and related technologies. Almost all laboratories in the fields of science and engineering have been mediated by computers. As such, there are many lab devices today which are operated through a computer-based interface. Thus, the nature of accessing lab equipment may not differ greatly, whether students make physical contact or interact remotely through a virtual interaction panel.

To find out the types of laboratories, the first step distinguishes between activities that are "Hands-on" and virtual (simulated), locally or distributed, and single users or multi-users. The following are the criteria that allow us to establish initial orientations regarding various laboratory environments (Figure 1): 1) the nature of lab equipment (physical or virtual); 2) access mode for doing activities (local or remote access).

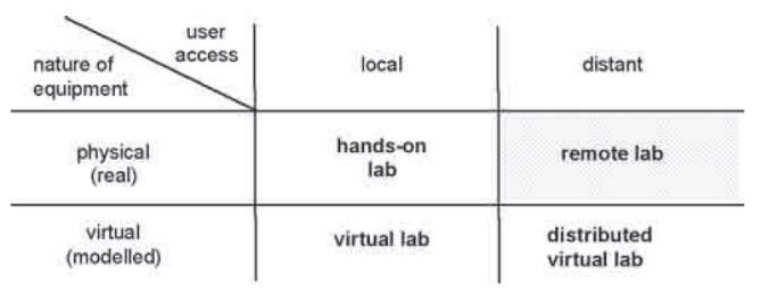

Figure 1. Laboratory environments

In Figure 1 above it appears that the Remote Lab plays a role in the physical environment, allows "Hands-on lab", and can be used remotely (online), so that psychomotor skills can be fulfilled.

\section{METHOD}

The research Remote Laboratory as a New Tool for Learning Practicum Online and Realtime in Digital Practicum Subjects. The first stage of research is a type of research development (R\&D). According to Gay (1990), a research and development (R\&D) approach, the main goal is not to test theories, but to develop and validate the tools used to work effectively and be ready for use. The development of 
hardware and software in the form of Information Technology-based media is carried out with an engineering approach where the stages are: analysis, design, implementation, and evaluation.

At each stage of this research and development an analysis will be carried out in accordance with the aims and objectives of the stage. In general, the analysis used in this study is descriptive analysis that will describe the results of development, validator responses and the results of trials. Analysis of software and hardware is carried out by considering the minimum specifications, with reference to software development for the media, namely efficiency and effectiveness, reliability, maintainability, usability, accuracy of application selection, compatibility, packaging, documentation and reusability.

\section{RESULTS AND DISCUSSION}

\section{Result}

\section{Development}

Development and Implementation is focused on the Practice of Digital Electronics subjects. Digital Electronics is one of the Basic subjects in Electronics Department curriculum. In the audio video engineering department there are competencies that students must master, one of which is digital electronics competence. Digital electronics subjects consist of Basic Logic Gates (AND Gate, OR Gate, NAND Gate, NOR Gate, NOT Gate, EX-OR Gate, EX-NOR Gate). The Remote Lab development process begins with several stages, namely the needs analysis and preliminary studies to Evaluation. In Figure 2 is the development process so that the final prototype is obtained.

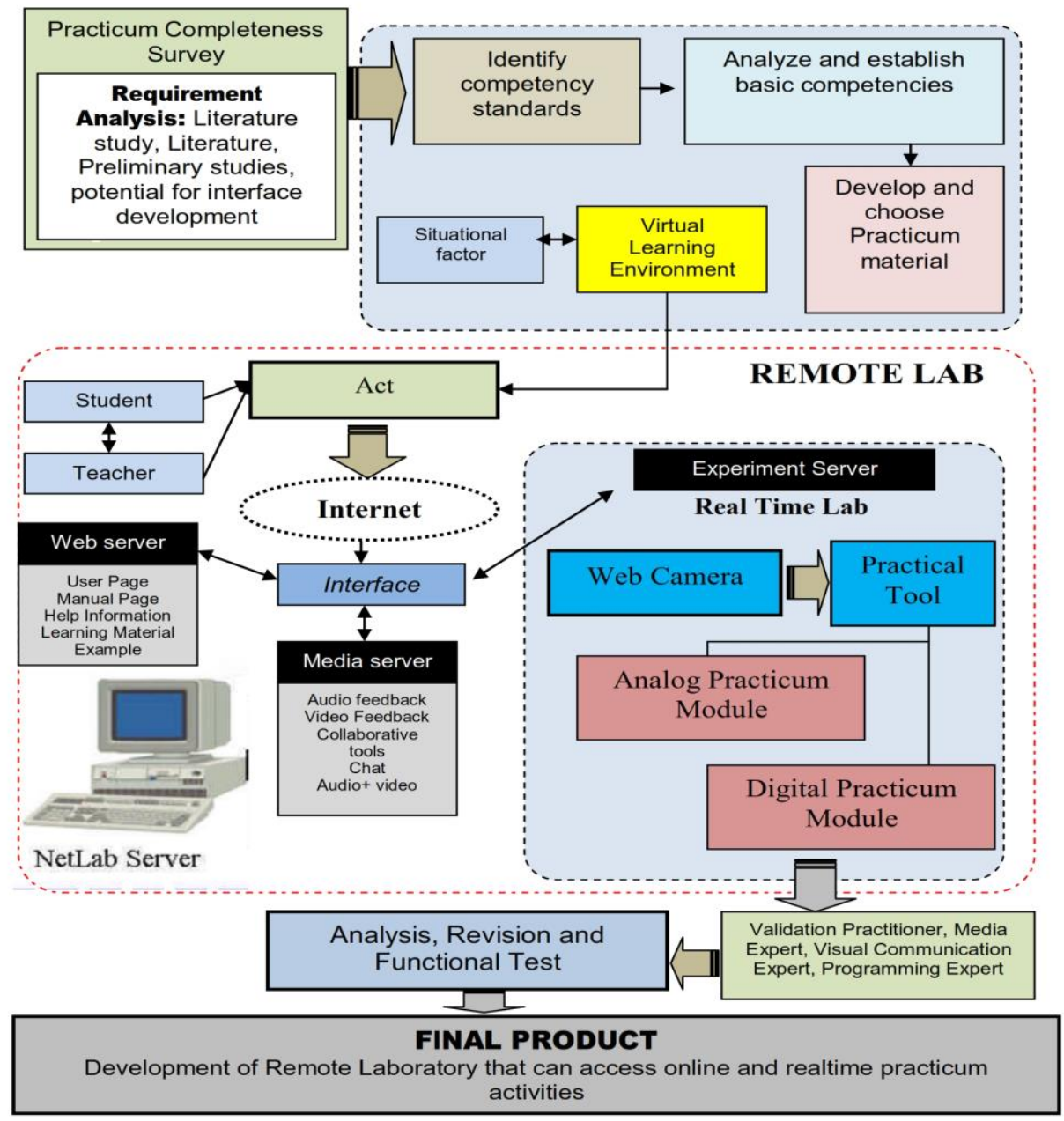

Figure 2. Remote Lab Development Procedure 


\section{Remote-Lab Data Validation and Repair}

The data obtained in this study are data from Expert validation. Expert validation data consists of three material experts, Programming experts and media experts. Data obtained through assessments, suggestions, and comments from media experts, programming experts, and material experts regarding the quality of the Remote LAB developed in this study. Validation data from media experts and material experts are used as a reference for revising the initial product.

Material Expert Validation Data. Material experts emphasize the evaluation of Remote Laboratory on aspects of the material such as aspects of the material / content, and aspects of practical design. Based on expert assessment of the material on the subjects developed integrated into the Website has been eligible to be tested.

Content aspect. The content / material aspect consists of the quality of the material, and the quality of the language. Material expert's assessment of this aspect is shown in table 1 . The results of quantitative conversion to qualitative data on a scale of 5 through media experts are described in table 2.

Tabel 2. Evaluation of Remote-Lab Content / Material Aspects by Material Experts

\begin{tabular}{|c|c|c|c|}
\hline \multirow[b]{2}{*}{ Aspect } & & \multicolumn{2}{|c|}{ Total Score } \\
\hline & & $\begin{array}{c}\text { Average } \\
\text { Score }\end{array}$ & Criteria \\
\hline $\begin{array}{l}\text { Quality Of } \\
\text { Materials }\end{array}$ & & 4,4 & $\begin{array}{l}\text { Very } \\
\text { good }\end{array}$ \\
\hline $\begin{array}{l}\text { Quality } \\
\text { Language }\end{array}$ & Of & 4,5 & $\begin{array}{l}\text { Very } \\
\text { good }\end{array}$ \\
\hline
\end{tabular}

Practical design aspects consist of consistency with 15 indicators, practicum strategy with 7 indicators, training and test with 4 indicators, method selection with 4 indicators, and motivation with 2 indicators. Material expert assessment of practicum design aspects is shown in table 3.

Tabel 3. Evaluation of Remote Lab practicum design aspects by Material Experts

\begin{tabular}{lccc}
\hline \multirow{2}{*}{ Aspect } & \multicolumn{2}{c}{ Total Score } \\
\cline { 2 - 3 } & $\begin{array}{c}\text { Average } \\
\text { Score }\end{array}$ & Criteria \\
\hline Consistency & 4,5 & $\begin{array}{l}\text { Very } \\
\text { good }\end{array}$ \\
Practicum Strategy & 4,4 & $\begin{array}{l}\text { Very } \\
\text { good }\end{array}$ \\
$\begin{array}{l}\text { Exercise Exercise } \\
\text { Test }\end{array}$ & And & 4,3 & $\begin{array}{l}\text { Very } \\
\text { good }\end{array}$ \\
\hline
\end{tabular}

\begin{tabular}{ccc}
\hline \multirow{2}{*}{ Aspect } & \multicolumn{2}{c}{ Total Score } \\
\cline { 2 - 3 } & $\begin{array}{c}\text { Average } \\
\text { Score }\end{array}$ & Criteria \\
\hline Selection Method & 4,4 & $\begin{array}{c}\text { Very } \\
\text { good }\end{array}$ \\
\hline Average & 4.4 & $\begin{array}{c}\text { Very } \\
\text { good }\end{array}$ \\
\hline
\end{tabular}

Media Expert Validation Data. Media experts who become validators in this development product are composed of several competent experts in their fields related to the Remote Lab being developed. To study the Remote Lab, 3 skills are required as follows: 1) multimedia experts; 2) programming expert; 3) visual communication expert. Media experts focus on evaluating Remote Lab on aspects of media such as aspects of appearance, aspects of Real-Time, and aspects of programming. Based on the media expert's assessment of the subjects developed integrated into the website it is worth testing further with a few minor improvements. Details of the assessment results are described as follows.

Display aspects (visual) consist of text readability in the trainer, use of language in the trainer, image quality in the trainer, harmony and color accuracy in the trainer, layout techniques (layout) in the trainer, placement and accuracy of the button on the User Interface, and the quality of the resolution Web Camera display. The assessment of media experts on this aspect is shown in table 4.

Tabel 4. Evaluation of Remote Lab (Visual) Display Aspects by Media Experts

\begin{tabular}{|c|c|c|}
\hline \multirow[b]{2}{*}{ Aspect } & \multicolumn{2}{|c|}{ Total score } \\
\hline & $\begin{array}{c}\text { Average } \\
\text { Score }\end{array}$ & Criteria \\
\hline Text On Trainer & 4,48 & Very good \\
\hline Language in Trainers & 4,60 & Very good \\
\hline Image on the Trainer & 4,32 & Very good \\
\hline Color on the Trainer & 4,43 & Very good \\
\hline $\begin{array}{l}\text { Component Layout on } \\
\text { the Trainer }\end{array}$ & 4,53 & Very good \\
\hline $\begin{array}{l}\text { Button on the User } \\
\text { Interface }\end{array}$ & 4,33 & Very good \\
\hline $\begin{array}{l}\text { Web Camera Display } \\
\text { Resolution }\end{array}$ & 4,60 & Very good \\
\hline Average & 4.47 & Very good \\
\hline
\end{tabular}

The real-time aspect consists of an explanation of abstract and complex concepts consisting of 5 indicators, real-time application consisting of 5 indicators, practicum form consists of 5 indicators, completeness of the 
facility consists of 4 indicators, Control technique consists of 2 indicators, theoretical proof consists of 1 indicator, and methodology consists of 2 indicators. The assessment of media experts on this aspect is shown in table 5.

Tabel 5. Assessment of the Real-Time Aspects of Remote Lab by Media Experts

\begin{tabular}{lcc}
\hline \multicolumn{1}{c}{ Aspect } & \multicolumn{2}{c}{ Total Score } \\
\cline { 2 - 3 } & $\begin{array}{c}\text { Average } \\
\text { Score }\end{array}$ & Criteria \\
\hline $\begin{array}{l}\text { Explanation of } \\
\text { Abstract and }\end{array}$ & 4,40 & Very good \\
$\begin{array}{l}\text { Complex Concepts } \\
\text { Real-time }\end{array}$ & & \\
application & 4,52 & Very good \\
$\begin{array}{l}\text { Form of Practicum } \\
\text { Completeness }\end{array}$ & 4,60 & Very good \\
Control Technique & 4,20 & Good \\
(Controller) & 4,60 & Very good \\
$\begin{array}{l}\text { Proof of Theory } \\
\text { Methodology }\end{array}$ & 4,80 & Very good \\
\hline \multicolumn{1}{c}{ Average } & 4,40 & Very good \\
\hline
\end{tabular}

Programming Aspects. The programming aspect consists of programming, interaction, navigation. The assessment of media experts on this aspect is shown in Table 6 .

Tabel 6. Evaluation of Remote Lab Programming Aspects by Media Experts

\begin{tabular}{|c|c|c|}
\hline \multirow[b]{2}{*}{ Aspect } & \multicolumn{2}{|c|}{ Total Score } \\
\hline & $\begin{array}{c}\text { Average } \\
\text { Score } \\
\end{array}$ & Criteria \\
\hline Programming & 4,59 & $\begin{array}{l}\text { Very } \\
\text { good }\end{array}$ \\
\hline Interaction & 4,63 & $\begin{array}{l}\text { Very } \\
\text { good }\end{array}$ \\
\hline Navigation & 4,51 & $\begin{array}{l}\text { Very } \\
\text { good }\end{array}$ \\
\hline Average & 4,57 & $\begin{array}{l}\text { Very } \\
\text { good }\end{array}$ \\
\hline
\end{tabular}

\section{Analysis of the Effectiveness and Practical Use of Remote Lab}

One way to determine the effectiveness and practicality of the model is through the assessment of experts and practitioners based on the mastery of the theory and the experience they have stated that the Remote-Lab model can be said to be effective or not. The results of the questionnaire assessment regarding product effectiveness are presented in Table 7.
Tabel 7. Remote Lab Effectiveness Assessment

\begin{tabular}{lcc}
\hline Effectiveness Indicator & $\begin{array}{c}\text { Average } \\
\text { Score }\end{array}$ & Criteria \\
\hline $\begin{array}{l}\text { Achieve increased } \\
\text { performance } \\
\text { (competence) }\end{array}$ & 4,2 & Effective \\
$\begin{array}{l}\text { Improving student } \\
\text { performance for the } \\
\text { completion of the } \\
\text { material }\end{array}$ & 4,8 & $\begin{array}{c}\text { Very } \\
\text { Effective }\end{array}$ \\
\hline $\begin{array}{l}\text { Average Overall Score } \\
\text { Every }\end{array}$ & 4,56 & $\begin{array}{c}\text { Vective } \\
\text { Effection }\end{array}$ \\
\hline
\end{tabular}

From Table 7 to assess the effectiveness of the Remote Lab product, several indicators of assessment regarding the achievement of work improvement (competency) are given, averaging a score of 4.2 or being in the effective category. Assessment of improving the performance of students for completing the material obtained a score of 4.8 or in very Effective category. Thus the overall overall effectiveness of the product obtained a mean score of 4.56 or is in the very effective category. This means that the products developed based on the responses of practical subjects teachers in SMKs meet the requirements for excellent product effectiveness.

Furthermore, to see the Remote Lab products developed in this study had met the practical requirements through several assessment indicators as presented in Table 7, the average score of overall aspects was 4.9 in the very practical category. Indicators stating practicality are elaborated with four assessment indicators as follows: First, Students can carry out and complete practicum objectively according to the flow and procedures in RemoteLab scores obtained by a mean of 4.8 or are in the very practical category. This is very practical when compared to practicum in a conventional laboratory. One piece of equipment is practiced by 4-5 students so that the completion of the practicum does not run objectively because only one person works and the others only watch, also in a conventional laboratory only intelligent students only can practice well. Second, the teacher can directly conduct an assessment and scoring of the results of student practicum stored in the Remote-Lab program database obtained a mean score of 5 or with a very practical category. Unlike the case in conventional laboratories the teacher must observe students one by one carefully the course of the practicum carried out by students. Third, Remote-Lab installed on Smartphone Participants can be directly accessed 
to do the practicum obtained by a score of 5 with a very practical category. Fourth, everything needed in the Remote Lab has been provided including tools and materials, measuring instruments, and data sheet books obtained a mean score of 4.8 with a very practical category.

Tabel 8. Practical Assessment of Remote Lab products

\begin{tabular}{|c|c|c|}
\hline Practicality Indicator & $\begin{array}{r}\text { Rerata } \\
\text { Skor }\end{array}$ & Kategori \\
\hline $\begin{array}{l}\text { Students can carry out and } \\
\text { complete practicum } \\
\text { objectively according to the } \\
\text { flow and procedures in the } \\
\text { Remote Lab }\end{array}$ & 4,8 & $\begin{array}{c}\text { Sangat } \\
\text { Baik }\end{array}$ \\
\hline $\begin{array}{l}\text { Teachers can immediately } \\
\text { conduct assessments and } \\
\text { scoring of student } \\
\text { practicum results stored in } \\
\text { the Remote-Lab program } \\
\text { database }\end{array}$ & 5 & $\begin{array}{c}\text { Sangat } \\
\text { Baik }\end{array}$ \\
\hline $\begin{array}{l}\text { Remote-Lab installed on } \\
\text { the Smartphone Participants } \\
\text { can be directly accessed to } \\
\text { do the practicum }\end{array}$ & 5 & $\begin{array}{c}\text { Sangat } \\
\text { Baik }\end{array}$ \\
\hline $\begin{array}{l}\text { Everything needed in the } \\
\text { Remote Lab has been } \\
\text { provided including tools } \\
\text { and materials, measuring } \\
\text { instruments, and data sheet } \\
\text { books }\end{array}$ & 4,8 & $\begin{array}{c}\text { Sangat } \\
\text { Baik }\end{array}$ \\
\hline Average Overall Score & 4,9 & $\begin{array}{c}\text { Sangat } \\
\text { Baik }\end{array}$ \\
\hline
\end{tabular}

\section{Discussion}

The Remote Lab model of Digital Electronics is one form of interactive multimedia that can support conventional practice in real laboratories. From the needs analysis that has been carried out it is revealed that the Vocational School still has limited equipment and is inadequate for practical activities which is around $30 \%$ complete with facilities (Hendra, 2013), further practicum activities in Remote Labs are badly needed by students, virtual practicum plans approve a lot. Furthermore, based on vocational teacher interviews, that digital subjects are basic subjects that require concepts and logic used in many majors such as Communication Electronics, TKJ, Audio Video, Mechatronics, and Industrial Electronics. Completeness for practicum in electronics subjects in vocational schools is still lacking and requires equipment while the existing equipment tools and materials for digital electronics practice have been damaged (David Lowe, 2011) and many of its components are difficult to obtain because of budget constraints and the components are no longer produced. Next interview with one of the subject matter teachers at SMKN 2 Depok Sleman Yogyakarta in 2018 during a visit to Yogyakarta that digital electronics is one of the practical subjects that have a lot of sub topics but limited time in carrying out the practicum, this is the problem in streamlining digital electronics subjects.

After seeing the conditions and needs regarding the need for a learning strategy that is Distance Learning through Remote Lab, the next step is to search for models and designs that will be developed. The Determination of the model is intended to choose the right model and look for references to the model to be developed. While the design determination concerns the software that will be used in developing Remote Labbased learning in this case using the Arduino UNO Microcontroller, IoT, Android Applications, Interface Arrangements.

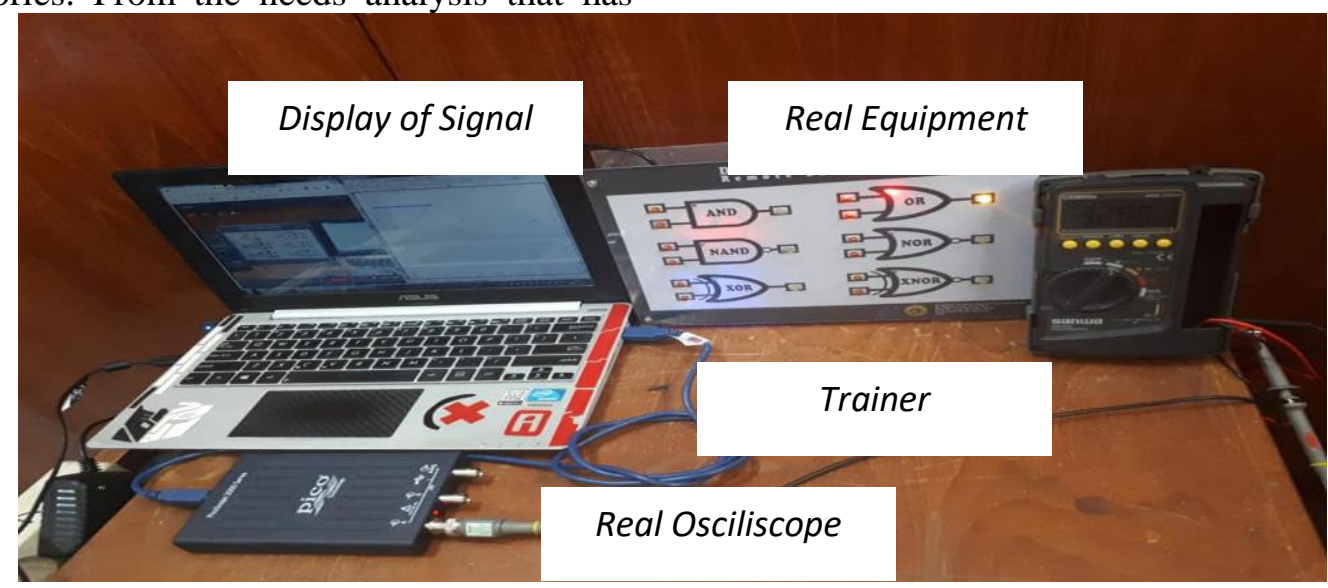

Figure 3. Implementation of Remote Laboratory Digital Electronic Subjects 


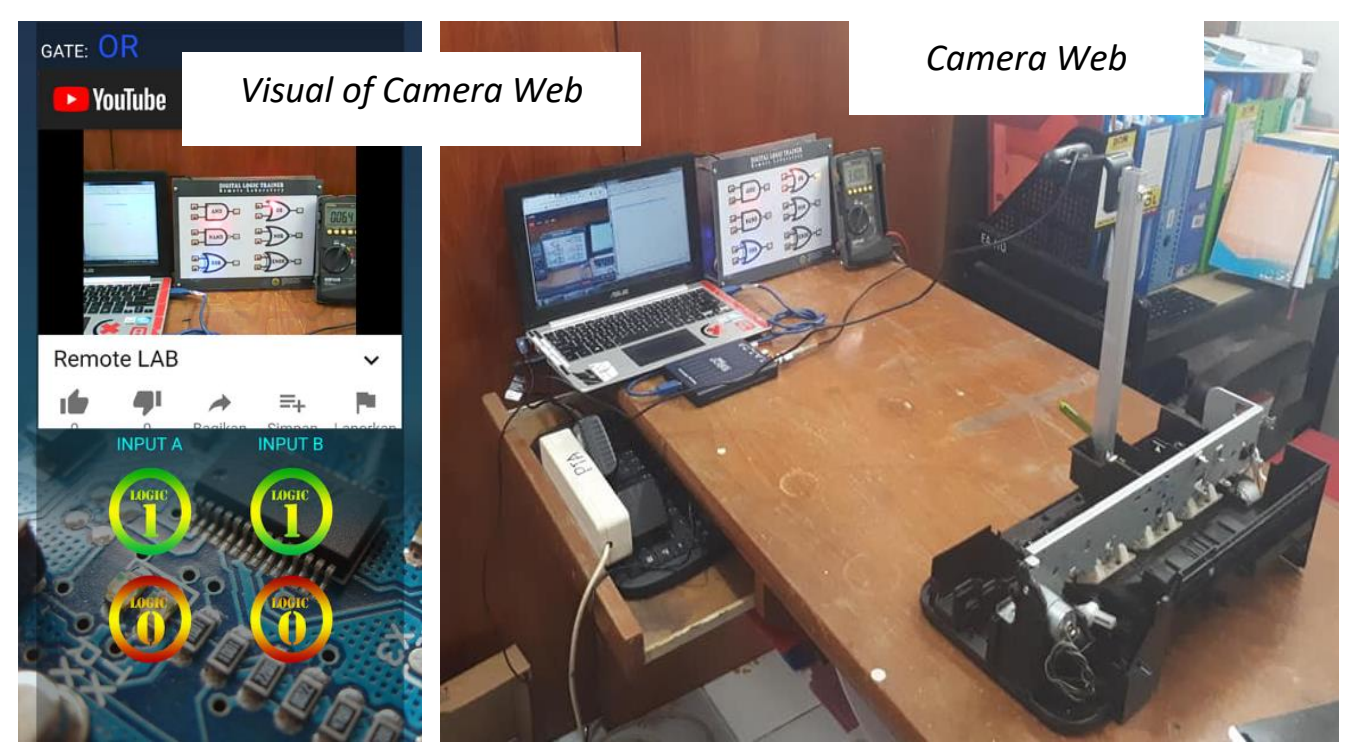

Figure 4. Remote Lab Controlled View with Webcamera

In doing the practicum by using the Remote lab. The device needs to be installed first. Furthermore, this virtual remote can be used online. to do a practicum measuring electric current and voltage, students still use the module as a guide in carrying out the practicum. Furthermore, measuring current and voltage, and waveforms with real devices are multimeters and oscilloscopes, and it is possible to use other real equipment. It was also expressed by Ingvar Gustavson (2013) that online students make circuits using real components and make real measurements on the circuits made.

Some of the results of this research study the advantages of the developed Remote Lab products are as follows: 1) The creation of online and realtime distance learning learning systems that can facilitate students who are constrained by distance and inadequate school facilities; 2) The creation of a tele-presence in the laboratory (telepresence), students do not need to be present in a real laboratory but carry out online practicum, so that their online presence is considered the same when present in the laboratory; 3) The creation of practical processes by conducting experiments on real equipment (not virtual); 4) The creation of practical learning with the concept of collaborative learning; 5) The creation of a practicum process whereby students can analyze real data with real experimental tools, and learn by trial and error; 6 ) the creation of the concept of flexibility in choosing the time and place to do the practicum. Give freedom of creativity to vocational students in carrying out practical activities without having to follow the schedule in the real laboratory; 7) limitations on resources owned by teachers in vocational schools and space in real laboratories. This type of limitation can cause delays in student learning activities in Vocational Schools, which may be faced with situations where they have to compete or wait for the availability of resources provided, other facts show that student experiments can be disrupted before concluding the results of experiments in a laboratory due to the need for shared tools; 8) the possibility of sharing equipment in a vocational school is usually very expensive.

\section{CONCLUSION AND SUGGESTION}

Based on the explanation presented above, it can be concluded that: 1) The use of Remote Lab can be applied in Vocational Schools by looking at the results of development based on the validation of material experts (Content Aspect of $4.45 \%$ with excellent category, and the Design Practicum aspect obtained a score of 4.4 with excellent category), validation of media experts (Display Aspect Visually obtained a score of 4.47 with a very good category, real-time aspects obtained a score of 4.5 with a very good category, programming aspects obtained a score of 4.57 with a very good category), Analysis of the Effectiveness and Practicality of Remote Lab Use obtained a score of 4.56 with a very effective category, then Practical Assessment of Remote Lab products obtained a score of 4.9 with a very practical category; 2) The creation of online and realtime distance learning practicum systems that can facilitate students who are constrained by distance and inadequate school facilities. Practical equipment so that learning outcomes in 
practicums can be met according to their competencies.

\section{REFERENCES}

Adams, Scott. (2001). GOD Debris: a though experiment. New York: Andrew McMeel Publishing, LLC.

David Lowe. (2011). UTS Remote Labs, Labshare, and the Sahara Architecture. University of Technology Sydney (Australia). ISBN 978-84-9830-398-8

Dieter Müller. (2007). Collaborative Remote Laboratories in Engineering Education: Challenges and Visions. Universität Bremen. Germany.

Djamarah, Syaiful Bahri \& Zain. (2002). Strategi belajar mengajar. Jakarta: Rineka Cipta.

Gay, L.R. (1987). Educational Research, competencies for analysis and aplication (3rd ed). Ohio: Merril publishing company.

Hartoyo.(1999). Kemampuan mengajar praktik guru sekolah menengah kejuruan negeri (SMKN) jurusan listrik di kota madya Yogyakarta. Tesis Magister, tidak diterbitkan, Universitas Negeri Yogyakarta, Yogyakarta.

Hendra, Jaya. (2012). Praktikum Berbasis Simulasi Komputer 3-Dimensi Pada Mata Kuliah Elektronika Digital. Jurnal JETC, Volume 7, Nomor 1, Des 2012.

Hendra, Jaya. (2013). Pengembangan Laboratorium Simulasi Praktikum Elektronika Digital di SMK. Disertasi. Universitas Negeri Yogyakarta.

Ingvar Gustavson. (2011). On Remote Electronics Experiments. Blenkige Institute of Technology, Karlskrona (Sweden). ISBN: 978-84-9830-398-8.

J. Ma \& J. V. Nickerson, (2006). Hands-on, simulated, and remote laboratories: $A$ comparative literature review. ACM Computing Surveys, 38/3, 2006, pp. 1-24.

K. Kask, , (2009). A study of science teacher development towards open inquiry teaching through an intervention progamme. Disertasi doktor, tidak diterbitkan, Universitas Tartu, Estonia.
Muchlas. (2014). Pengembangan V-Lab Menggunakan Aplikasi Online Meeting dan Simulator Breadboard untuk Praktikum Elektronika Digital. Prosiding Pertemuan Ilmiah XXVIII HFI Jateng \& DIY, Yogyakarta, 26 April 2014 ISSN : 0853-0823.

Orlich, D.C, et.al.(2007). Teaching strategies: A guide to effective instruction. New York: Houghton Mifflin Company.

Purwanti Widhy. (2012). Pemanfaatan Laboratorium Virtual Pada Pembelajaran IPA. "Pelatihan Digitalisasi Perangkat dan Media Pembelajaran IPA Untuk Meningkatkan Kualitas Pembelajaran di Era Baru" di SMP 3 Muhammadiyah Depok.

Rini Widyastuti, Iga Setia Utami. (2018). Development of Product-Based Job Sheet as Instructional Media in Vocational Education. Journal of Educational Science and Technology (EST). 4 (2) pp 119-125. DOI:

http://dx.doi.org/10.26858/est.v4i2.6064

Sege, Djafar. (2005). Pengaruh motivasi, pembelajaran, dan fasilitas terhadap kemempuan kerja las siswa SMK Muhammadiyah 3 Yogyakarta. Tesis Magister, tidak diterbitkan, Universitas Negeri Yogyakarta, Yogyakarta.

Soemanto, Wasty. (2003). Psikologi Pendidikan. Jakarta: Rineka Cipta.

S. M. Alessi \& S. R. Trollip, (2001). Multimedia for learning: Methods and development, Boston, Allyn and Bacon.

Yamin, Martinis,(2005). Strategi Pembelajaran Berbasis Kompetensi. Jakarta: Gaung Persada Press.

Zorica Nedic. (2003) Remote Laboratories Versus Virtual And Real Laboratories. 33rd ASEE/IEEE Frontiers in Education Conference 